\title{
Encouraging Diversity of Dialogue as part of the iSchools Agenda. ${ }^{1}$
}

\author{
Simon Mahony (http://orcid.org/0000-0001-9811-9381)*, \\ simon.mahony@gmail.com \\ Yaming Fu (https://orcid.org/0000-0001-9736-4916)** \\ Corresponding author \\ yaming.fu.17@ucl.ac.uk
}

${ }^{*}$ (Research Centre for Digital Publishing and Digital Humanities, Beijing Normal University at Zhuhai, 519087, China)

**(Department of Information Studies, University College London, UK)

\begin{abstract}
This paper takes the conference themes of Diversity, Divergence, Dialogue and applies them to an analysis of the published topic headings and keywords from previous iConferences to determine the extent to which diversity is an important aspect within the iSchools community. It follows previous research from 2016 where Bogers and Greifeneder conducted a quantitative analysis of the metrics for submission and acceptance of papers for the 2014 iConference in Berlin. Their interest was in the potential for bias resulting from a lack of diversity in the established review process. We look at topic headings, language and country of presenters as a sub-set of diversity and how we might move away from the Anglophone dominance towards more demographic diversity and in doing so widen the channels for scholarly communication and dialogue. The move to a virtual conference removes any geolocational difficulties and competition for limited travel budgets. The 2021 Chinese track accepts submissions in Chinese, removing the difficulties of the English-language requirement for scholars of the host nation. Language, publication and travel are determining factors for encouraging and facilitating diversity; these should be reinforced within the iSchools movement to develop a sense of community with members as stakeholders so that they feel that they are part of a diverse but inclusive community. This Short Paper is the first stage in a wider study looking at the changes that the innovations for the 2021 iConference have on diversity, divergence, and dialogue for papers and published proceedings.
\end{abstract}

Keywords: Diversity, Community, Globalisation

\section{Introduction ${ }^{2}$}

The themes of iConference 2021, Diversity, Divergence, and Dialogue are very pertinent in these challenging times. How do we bring different (diverse) groups of people with dissimilar attitudes and opinions (divergence) together to facilitate communication (dialogue) that is equally shared and accessible to us all? Our paper looks at the challenge that faces us in a global community, such as the iSchools movement, and how we, as a community, might take a lead in demonstrating ways in which researchers, academics and practitioners can advance an agenda for diversity and divergence in our scholarly dialogue. 
We refer to the iSchools movement as a community as that is what it represents with members in an association, a Gesellschaft, based on occupation and common interest. ${ }^{3}$ As a scholarly and professional community there is the shared interest where we might communicate and collaborate but there are also the shared goals and values that we adhere to. Most of the 'association' takes place online but, importantly, there is the annual iConference which brings people together from the virtual to the physical. This is the place where networks are developed, and casual conversations may result in future collaborations; it brings the community of iSchool members together. A significant determinant of the iConference is its international nature and global reach. Looking back through the history of the iSchools movement, it is clear that the epicentre was North America. All iConferences before 2014 were held in the USA, with the exception of 2012 in Toronto; then came Europe in 2014 (Berlin), UK (Sheffield) in 2018, and Sweden (Boras) in 2020. ${ }^{4}$ The iConference became truly global in 2017 when it was hosted at Wuhan and now in 2021 at Renmin. Following the conference move beyond North America, Bogers and Greifeneder (2016) conducted a quantitative analysis of the metrics for submission and acceptance of papers, mostly concerned with review balance and how that might be corrected.

When we look at the regional distribution of iSchool members the North American Directory lists 53 institutions, the European Directory 33, and Asia Pacific $31 .{ }^{5}$ The latter is the largest region by land mass, rather than population or representation in the iSchools, including Australia and East Asia with 13 iSchools in mainland China. The Board of Directors includes members representing each of these regions. ${ }^{6}$ The iSchools, then, is a truly global community but, nevertheless, a mainly virtual one with dedicated initiatives and committees all conducted online.

A community is mostly identified by what it does and if it is to flourish and grow, particularly a virtual one, its members need to interact with other members to give them a sense of belonging ${ }^{7}$ and have an emphasis on iSchool research connectivity. This is the importance of the iConference and the associated proceedings which connects members of the global community to give a point of reference for members to come together in person to share research output under the common banner and aegis of iSchools. This strengthens the weaker community ties of Gesellschaft to give focus and cohesion by giving a locus and annual physical point of contact for members; it is especially important for new researchers in promoting communications, making connections, and strengthening collaborations. As a community at a distance this temporary locus of the iConference places us somewhere between Gesellschaft and Gemeinschaft, ${ }^{8}$ serving to strengthen and consolidate the ties between members. The 2020 and 2021 iConferences are exceptions with the pandemic related travel restrictions; they break the geolocation limitations thus increasing the 'association' with enhanced possibilities for communication and a globalised research agenda. The iConference has a global reach but does that lead to diversity and divergence of dialogue as evidenced by the papers and publications?

\section{Methodology}

This paper is an initial study into aspects of diversity within the iSchools community to address questions of inclusion; to what extent do our members have an equal voice and opportunity to be heard? The iSchools movement certainly crosses continents and from the 'About' statement envisions 'a future in which the iSchool 
Movement has spread around the world'. ${ }^{9}$ The question is whether or not this global reach does indeed lead to 'diversity and divergence of dialogue' and, if not, how might this be encouraged and facilitated. The majority of the iSchool community are found outside its North American roots (Asia Pacific 31, Europe 33, North America $53)^{10}$ but is this globalisation matched by the iConference papers and publications?

From Bogers and Greifeneder (2016), overall, '[t]he 2014 European iConference saw $109.8 \%$ more submissions from Europe relative to 2015, whereas the 2015 North American iConference saw 19.5\% more submissions from North America than in 2014.' They discussed the cultural bias in the review process following an analysis of the review data from 2014 (Berlin) and looking ahead to Wuhan the following year. ${ }^{11}$

Diversity is a wide-ranging term, including gender, race, orientation, as well as intellectual content, but analysing these requires more data than can be found in the public domain and hence, as our starting point, we focus on language and country. As a Short Paper the scope is necessarily limited and our data is taken from the published iConference Past Proceedings, the Papers Proceedings (2018-2020) and conference summaries from the inaugural event (2005) up to and including $2020 .^{12}$ Additional material published in IDEALS, other than 2009, and ADC has not been included as the format did not match the conference summaries; nevertheless, we intend to include these in our next phase to expand the corpus and deepen the analysis. Our emphasis is on the presenters and publications, along with stated conference themes and keywords (where included). The topic titles were collected and run through a simple concordance programme (MonoConc Pro), to identify commonly occurring words and themes; as titles rather than natural language extracted from abstracts or content, there was no need to exclude stop words and simple frequency lists, concordances and collocations were generated.

The Springer published proceedings only cover the last three years but, nevertheless, give a good indication of topical interests and concerns; considering the presenters and topics shows movement of both over time. A more exhaustive study would need to include an analysis of the representation within the membership itself as well as the executive postholders and represents a useful follow up project which would also benefit from cross-tabulation of author nationality with keywords.

\section{Results}

Table 1: iConference participants and host country by year.

\begin{tabular}{|l|l|l|}
\hline \multicolumn{3}{|c|}{$\begin{array}{c}\text { iConference participants by year } \\
\text { (no conference is recorded for 2007) }\end{array}$} \\
\hline Year & Participants & Host country \\
\hline 2005 & No data & USA \\
\hline 2006 & 317 & USA \\
\hline 2008 & 277 & USA \\
\hline 2009 & 305 & USA \\
\hline 2010 & 346 & USA \\
\hline 2011 & 538 & USA \\
\hline 2012 & 486 & Canada \\
\hline 2013 & 512 & USA \\
\hline 2014 & 450 & Germany \\
\hline 2015 & 531 & USA \\
\hline
\end{tabular}




\begin{tabular}{|l|l|l|}
\hline 2016 & 467 & USA \\
\hline 2017 & 482 & China \\
\hline 2018 & 468 & UK \\
\hline 2019 & 539 & USA \\
\hline 2020 & 390 (virtual) & Sweden \\
\hline
\end{tabular}

Table 1 lists the iConference host country and number of participants by year. The information on the published conference summaries is not consistent and has developed and expanded along with the conference. The Conference Summary for 2014, the first to be held outside North America (Berlin), gives a breakdown of the countries represented as well as the total number of participants $(450) .{ }^{13}$ The following year (USA) has similar data on the public page but this is not available publicly for other iConferences. ${ }^{14}$

Table 2. Geographic breakdown of participants for 2014 and 2015

\begin{tabular}{|l|l|l|l|}
\hline \multicolumn{3}{|c|}{$\begin{array}{c}\text { Geographic breakdown of participants for the years 2014 and 2015 } \\
\text { (data from conference summaries - Endnote reference \#14 and \#15) }\end{array}$} \\
\hline \multicolumn{1}{|c|}{ Year } & \multicolumn{2}{|c|}{$\mathbf{2 0 1 4}$} & \multicolumn{1}{c|}{$\mathbf{2 0 1 5}$} \\
\hline iConference location & Berlin, Germany & & $\begin{array}{l}\text { Newport Beach, } \\
\text { California, USA }\end{array}$ \\
\hline Host institution & $\begin{array}{l}\text { Humboldt } \\
\text { University, Berlin }\end{array}$ & & $\begin{array}{l}\text { University of } \\
\text { California, Irvine }\end{array}$ \\
\hline Total number participants & 450 & & 531 \\
\hline Countries represented & 30 & & 25 \\
\hline $\begin{array}{l}\text { Top 10 countries by } \\
\text { number of participants }\end{array}$ & Only eight listed & & Ten listed \\
\hline USA & 242 & USA & 404 \\
\hline UK & 26 & Canada & 18 \\
\hline Denmark & 26 & China & 15 \\
\hline Canada & 22 & Germany & 14 \\
\hline Germany & 22 & UK & 10 \\
\hline Japan & 12 & South Korea & 9 \\
\hline China & 10 & Denmark & 7 \\
\hline Sweden & 8 & Japan & 7 \\
\hline & & Spain & 5 \\
\hline & & Sweden & 5 \\
\hline
\end{tabular}

Table 2 shows an increase in non-North American participants with the iConference held in Europe. This is as expected with easier travel for Europeans but, although it is not possible to make strong claims based on data from two years, nevertheless, it illustrates a turn that is worth further investigation. The overall number of participants is higher in 2015 but with fewer countries represented and following this there seems to be interest in the demographic of participants. ${ }^{15} \mathrm{~A}$ more complete data set could be determined for the presenters by correlating names and affiliations from the conference programmes, although, that would not return the global representation of the 'participants' as non-presenters would not be included. 
An additional issue is that declared affiliation would be for participants' current institution rather than indicative of their nationality or first language.

For individual conferences, the programmes do not show themed sessions that could be used for analysis, although from 2017 (Wuhan) the Conference Summary lists a series of organisational headings in the Supporting Materials. ${ }^{16}$ The Springer proceedings are edited volumes with the content seemingly broken down according to the preferences of the editors rather than any fixed format. Each volume has local editors (different US states 2019) but the number and wording of the section headings is very different. The number of articles published are 75 in 2020, 77 in 2019 and 82 in 2018 and hence fairly consistent and match the number of accepted papers with a stated acceptance rate of $30 \%, 33 \%, 30 \%$ respectively. The subject headings are, however, very different with the 2019 editors taking a much more granular and verbose approach to the organisation of the material (see Table $3)$.

Table 3: Topic Headings taken from the published proceedings, Springer LNCS (2018-2020)

\begin{tabular}{|c|c|c|}
\hline \multicolumn{3}{|c|}{ Topic headings in the published proceedings: Springer LNCS } \\
\hline $\begin{array}{l}2020 \text { Sustainable } \\
\text { Digital Communities }\end{array}$ & $\begin{array}{l}2019 \text { Information in } \\
\text { Contemporary Society }\end{array}$ & $\begin{array}{l}2018 \text { Transforming } \\
\text { Digital Worlds }\end{array}$ \\
\hline $\begin{array}{l}\text { Sustainable } \\
\text { Communities }\end{array}$ & $\begin{array}{l}\text { Scientific Work and Data } \\
\text { Practices }\end{array}$ & Social Media \\
\hline Social Media & $\begin{array}{l}\text { Methodological Concerns in } \\
\text { (Big) Data Research }\end{array}$ & $\begin{array}{l}\text { Communication Studies } \\
\text { and Online Communities }\end{array}$ \\
\hline Information Behavior & $\begin{array}{l}\text { Concerns About "Smart" } \\
\text { Interactions and Privacy }\end{array}$ & $\begin{array}{l}\text { Mobile Information and } \\
\text { Cloud Computing }\end{array}$ \\
\hline Information Literacy & $\begin{array}{l}\text { Identity Questions in Online } \\
\text { Communities }\end{array}$ & $\begin{array}{l}\text { Data Mining and Data } \\
\text { Analytics }\end{array}$ \\
\hline User Experience & $\begin{array}{l}\text { Measuring and Tracking } \\
\text { Scientific Literature }\end{array}$ & Information Retrieval \\
\hline Inclusion & $\begin{array}{l}\text { Limits and Affordances of } \\
\text { Automation }\end{array}$ & $\begin{array}{l}\text { Information Behaviour } \\
\text { and Digital Literacy }\end{array}$ \\
\hline Education & $\begin{array}{l}\text { Collecting Data about } \\
\text { Vulnerable Populations }\end{array}$ & Digital Curation \\
\hline Public Libraries & $\begin{array}{l}\text { Supporting Communities } \\
\text { Through Public Libraries and } \\
\text { Infrastructure }\end{array}$ & $\begin{array}{l}\text { Information Education } \\
\text { and Libraries }\end{array}$ \\
\hline Archives and Records & $\begin{array}{l}\text { Information Behaviors in } \\
\text { Academic Environments }\end{array}$ & \\
\hline Future of Work & $\begin{array}{l}\text { Data-Driven Storytelling and } \\
\text { Modeling }\end{array}$ & \\
\hline Open Data & Online Activism & \\
\hline Scientometrics & $\begin{array}{l}\text { Digital Libraries, Curation } \\
\text { and Preservation }\end{array}$ & \\
\hline $\begin{array}{l}\text { Al and Machine } \\
\text { Learning }\end{array}$ & $\begin{array}{l}\text { Social-Media Text Mining } \\
\text { and Sentiment Analysis }\end{array}$ & \\
\hline $\begin{array}{l}\text { Methodological } \\
\text { Innovation }\end{array}$ & $\begin{array}{l}\text { Data and Information in the } \\
\text { Public Sphere }\end{array}$ & \\
\hline
\end{tabular}




\begin{tabular}{|l|l|l|}
\hline & $\begin{array}{l}\text { Engaging with Multi-media } \\
\text { Content }\end{array}$ & \\
\hline & Understanding Online & \\
& Behaviors and Experiences & \\
\hline & Algorithms at Work & \\
& Innovation and & \\
& Professionalization in & \\
& Technology Communities & \\
\hline & Information Behaviors on & \\
& Twitter \\
\hline & Data Mining and NLP & \\
\hline & Informing Technology & \\
& Design Through Offline & \\
& Experiences & \\
\hline & Digital Tools for Health & \\
& Management & \\
\hline & Environmental and Visual & \\
& Literacy \\
\hline & Addressing Social Problems & \\
& in iSchools Research & \\
\hline & \\
\hline
\end{tabular}

Generating a simple concordance (Figure 1) of the topic headings (Table 3 ) shows the most frequent (and popular) terms in the titles of the published articles and hence the dominant terms in the accepted conference presentations: 'information, 'data' and 'communities'.

\begin{tabular}{|l|l|l||}
\hline \multicolumn{3}{|l|}{ Hh Corpus Frequency List } \\
\hline Count & Pct & Word \\
\hline 20 & $11.1732 \%$ & and \\
\hline 9 & $5.0279 \%$ & information \\
8 & $4.4693 \%$ & data \\
6 & $3.3520 \%$ & in \\
5 & $2.7933 \%$ & communities \\
4 & $2.2346 \%$ & libraries \\
4 & $2.2346 \%$ & digital \\
4 & $2.2346 \%$ & online \\
3 & $1.6760 \%$ & public \\
3 & $1.6760 \%$ & work \\
3 & $1.6760 \%$ & literacy \\
3 & $1.6760 \%$ & mining \\
3 & $1.6760 \%$ & social \\
3 & $1.6760 \%$ & behaviors \\
\hline \hline
\end{tabular}


Figure 1: word frequency of topic headings

Combining the most frequent term with its collocating words (Figure 2), gives 'information' and 'information behavio(u)r(s)', to be expected at an iConference, as the most frequent heading terms. Of particular interest for our study is that 'communities' is the third most common term and hence an important theme.

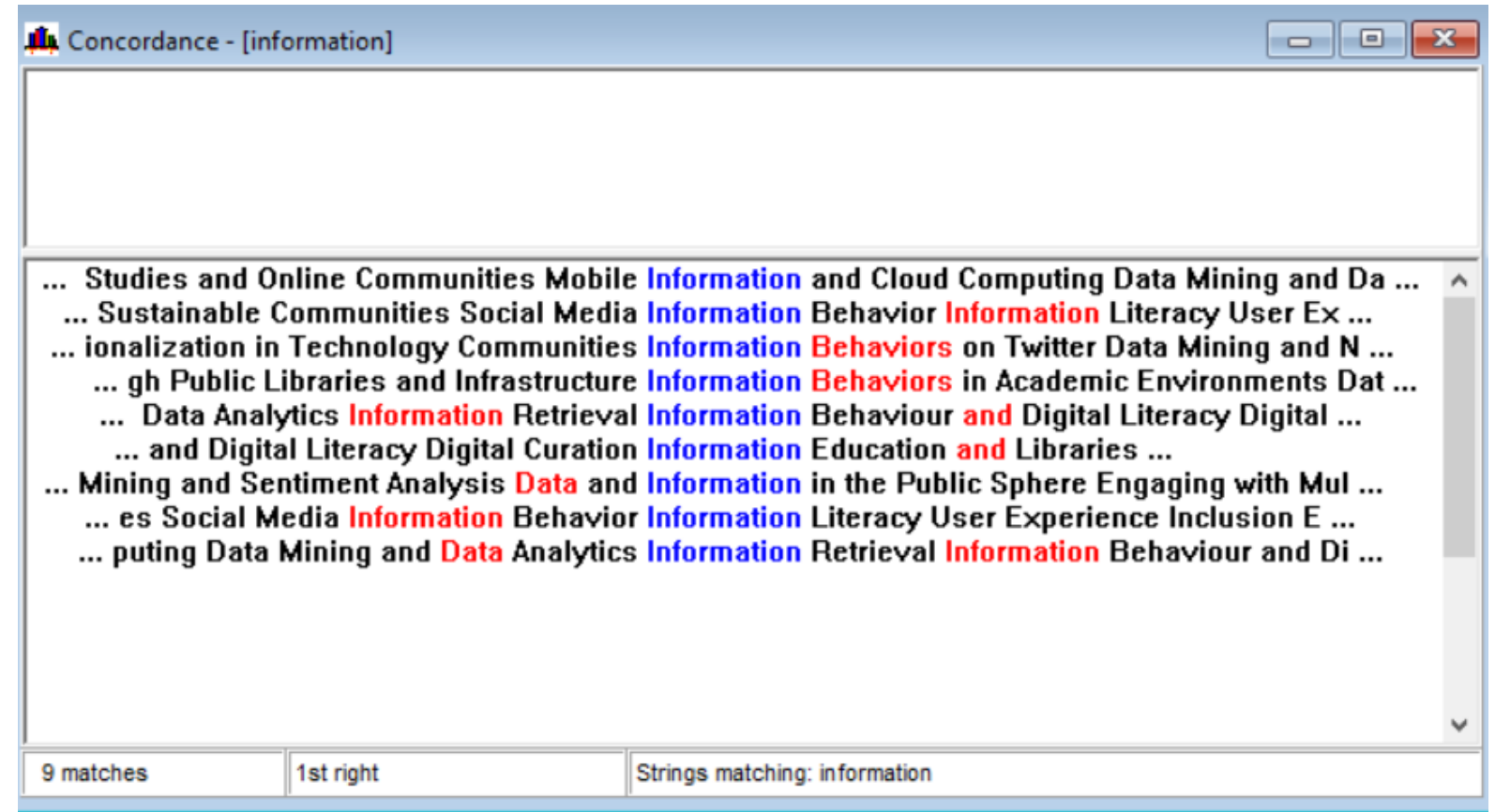

Figure 2: Key Word in Context concordance for 'information' within topic headings.

The second iConference held outside North America was at Wuhan in 2017 the first in the iSchools Asia Pacific region - with another category added to 'By the numbers': Chinese Papers (45) with more than either Completed Research Papers (30) or Preliminary Results Papers (36). Nevertheless, despite this special track and that the 2017 Supporting Materials and 2017 Proceedings IDEALS show many Asian names as presenters, 'all papers were written and presented in English'. ${ }^{17}$

Other changes in 2017 saw the introduction of a series of headings in the Supporting Materials, presumably, to group together the proposals by topics: 'Workshop Proposals and Results; Sessions for Interaction and Engagement Proposals; Special Panel Proposals; iSchool Best Practices Proposals; iSchools and Industry Partnership Presentations and Proposals.' ${ }^{18}$ These, however, reduced in number over the following years.

A brief analysis of the published keywords for all conferences (where given) shows the most frequent term to be 'social' (Figure 3 ) and when put into its immediate linguistic context (with associated words sorted) it links most often with 'networks' and 'networking' (Figure 4). This indicates the importance of both social and networking aspects to iSchool concerns and again emphasises the 'community' aspect, a focus of this paper. 


\begin{tabular}{|c|c|c|c|}
\hline \multicolumn{4}{|c|}{ Ih Corpus Frequency List } \\
\hline Count & Pct & Word & 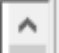 \\
\hline 9 & $7.4380 \%$ & social & \\
\hline 8 & $6.6116 \%$ & computing & \\
\hline 7 & $5.7851 \%$ & information & \\
\hline 6 & $4.9587 \%$ & networks & \\
\hline 5 & $4.1322 \%$ & and & \\
\hline 4 & $3.3058 \%$ & digital & \\
\hline 4 & $3.3058 \%$ & computer & \\
\hline 3 & $2.4793 \%$ & web & \\
\hline 3 & $2.4793 \%$ & wide & \\
\hline 3 & $2.4793 \%$ & world & \\
\hline 3 & $2.4793 \%$ & data & \\
\hline 3 & $2.4793 \%$ & education & \\
\hline 3 & $2.4793 \%$ & retrieval & \\
\hline 3 & $2.4793 \%$ & libraries & \\
\hline 3 & $2.4793 \%$ & archives & \\
\hline 3 & $2.4793 \%$ & systems & $\checkmark$ \\
\hline \multicolumn{4}{|c|}{121 words, 57 types } \\
\hline
\end{tabular}

Figure 3: word frequency of keywords

\begin{tabular}{|c|c|c|c|}
\hline \multicolumn{2}{|c|}{ Alh Concordance - [social] } & \multicolumn{2}{|c|}{ 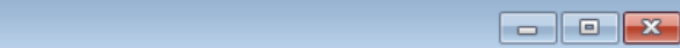 } \\
\hline \multicolumn{4}{|c|}{ 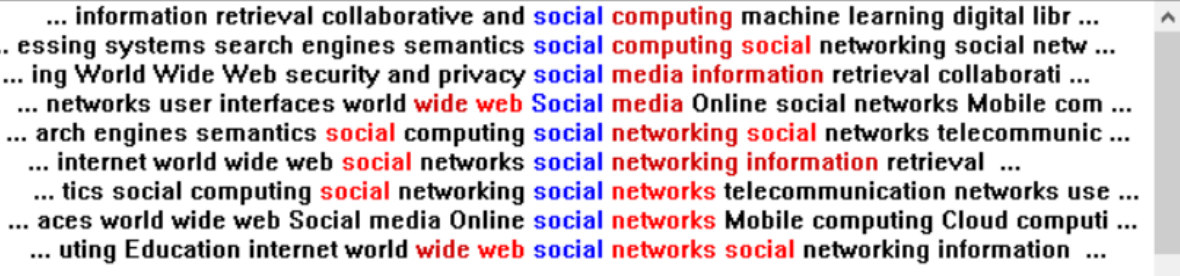 } \\
\hline 9 matches & 1st right, 1st left & Strings matching: social & \\
\hline
\end{tabular}

Figure 4: Key Word in Context concordance for 'social' within keywords.

\section{Discussion}

The analysis above is limited to the terms used in the titles of the published articles and the conference topic headings, rather than the content of abstracts or papers, but nevertheless they are indicative of clear trends.

The iConference has attracted growing numbers since the early days with a dip in 2020, the year of the global pandemic. With the move to Berlin (2014) the 
countries of participants were published and regions in the following year; an awareness seemed to be growing about the need to consider demographics with the move from North America. Wuhan (2017) saw the addition of a dedicated local Chinese track although proposals and presentations still needed to be in English. The recommendations of Bogers and Greifeneder (2016) were that reviewers should be more representative of the overall iSchools community by increasing the number of female and Asian reviewers to allow for more representative diversity of accepted papers. ${ }^{19}$

Another significant issue impacting on 'diversity of dialogue' is that of language. With its North American roots, the iSchools movement developed in an environment dominated by English as the language of the Internet (with ICANN) and the lingua franca of the Web (with the W3C Consortium). The medium in which we work and correspond has a bias towards the English language leading to linguistic differences and regional inequalities. ${ }^{20}$ This is also true of publishing where to have your work widely circulated and read, leading to more citations to support academic advancement and promotion, results in a distortion of the publication metrics. ${ }^{21}$ This has been corroborated by studies on the metrics of publication in the cognate disciplines of the Arts and Humanities (as counted in major indices such as Scopus and Web of Science) and how that along with citation counts has a clear Anglophone-bias, resulting not only in incentives for advancement but also for successful funding applications. ${ }^{22}$ Hence, there is pressure to publish in English, regardless of native language.

The track for Chinese papers in Wuhan 2017 still required papers and presentations to be in English. This was restrictive and particularly so with the difficulties of Chinese scholars to have papers accepted under the strict language requirements. The 2021 iConference at Renmin similarly has a special track for Chinese papers, but this time submissions 'are exempted from the English-language requirement and may be in Chinese. ${ }^{23}$ Looking at overall submissions and acceptances, tracking the data following Renmin would enable us to see whether dropping the English-language requirement would create a more equitable field.

\section{Conclusions}

Pulling all this together, what is it that facilitates dialogue and would help to encourage diversity within the iSchools movement? It is argued here that we should develop inclusiveness, a sense of community and ownership of the movement by its members. Members need to be stakeholders and feel that they are part of the community; that they have a voice, and most importantly that they are able to have a positive and valuable interaction with other members of the community; that the community is more than just a symbolic and intellectual construct but one that they can engage with.

Our membership is global and so the iConference needs to move away from Anglophone dominance. There seems to be a correlation between the location and the demographic of conference presenters with a greater number of non-North American attendees when held in Europe or Asia (see Table 2 and Bogers and Greifeneder (2016)). Travel seems an obvious restriction and, in competition for funds, institutional support is also fundamental for ensuing a diversity of participants, particularly for graduate students who may lack research budgets. This ability to make connections, establish relationships, and create networks is, to a great extent, dependent on institutional and financial constraints. Nevertheless, without this 
interconnection we limit the essential exchange of ideas that potentially lead to collaboration; faculties and funders need to be persuaded of this.

Consider the difficulties in getting a proposal accepted in a language other than your own. Allowing more diversity of languages for conference proposals, at a minimum that of the host nation, would go some way to increasing the possibility of more diverse dialogue. Without doing so, we are restricting our participants and our audience, and so limiting the reach and 'impact' of our research.

If we restrict our cultural perspective, we also restrict our field as we all learn from each other; inclusion benefits sustainable discussions among us. Without this, it is those English speakers who have no other language, and no incentive to engage outside the Anglophone sphere, that stand to lose the most.

Now, English has emerged as a de facto lingua franca - with of those of us who grew up speaking English losing the most, insofar as the widespread use of English makes it easy for us to ignore the importance of language and to avoid the challenge of mastering languages other than our own. No one would benefit more from a commitment to linguistic diversity than speakers of English. ${ }^{24}$

We need to be willing to engage with researchers and practitioners outside of our linguistic comfort zones, to reach out more widely to new audiences and to engage beyond our limited echo-chamber. Otherwise, we are destined to discuss our research interests only with those that we already know. Language is also an issue for conference organisation, with translation facilities to be considered as part of the package for conference funding. In addition, there are significant benefits for multilingual published proceedings to widen their circulation that could also be part of long-term strategic vision to create a truly global iSchools community.

The wish for this global iSchools community is clearly stated in 2020 by both Professor Sam Oh, the first Chair from the Asia-Pacific region: 'I knew from the start that I wanted to do whatever I could to further promote and develop the iSchool movement on a global scale. [...] It is my dearest wish that the iSchools will become truly international in every sense of the word'. ${ }^{25}$ And our incoming Chair, Professor Gobinda Chowdhury, 'Inclusiveness and diversity are key attributes of the iSchools community [...].'26 There is still some way to go to achieve this but movement with regards to language and concerns about demographics of conference participants are beginning to be addressed.

The 2020 iConference was moved online in response to the pandemic and so the expectation for those submitting proposals was for physical attendance. The announcement that the 2021 iConference would be a virtual one was accompanied by a three-week extension to the deadline for proposals. It will be interesting to see how this affects the demographic diversity of participants, the divergence of published papers, and opportunities for dialogue once the need to travel is removed; this is the topic for our iConference paper in preparation for 2022.

There is a general movement towards, at least, an interest in diversity but to enable any effective examination, the iConference organization needs to make demographic data of presenters and attendees available at a more granular level. This will enable a cross-tabulation and other analyses of language and country before moving into the wider diversity landscape. Data on submissions versus acceptance (and reason for nonacceptance) is needed to assess whether allowing non-English papers at Renmin has led to more equity. 
The organisers should be more flexible about languages for submission and presentation (at a minimum those of the host nation); encourage multi-lingual presentation of work (e.g. slides in two or multiple languages) to increase dialogue; consider multi-lingual publications of proceedings; having hybrid online/in-person formats to remove travel and funding related limitations; actively encourage wider participation and community engagement by funding bursaries and workshops.

\section{References}

\footnotetext{
${ }^{1}$ The final authenticated version is available online at https://doi.org/10.1007/978-3-030-71305-8_15

2 The authors would like to thank the anonymous reviewers for their helpful comments which have allowed us to strengthen this short paper as well as given us a clearer focus for our future work on this topic.
}

3 Tönnies, F. Community and Civil Society. Edited by Jose Harris, Translated by Margaret Hollis. 2001. Cambridge Texts in the History of Political Thought.

${ }^{4}$ Past Proceedings: https://ischools.org/Past-Proceedings (last accessed 14/09/2020)

5 iSchools Directory: https://ischools.org/Directory (last accessed 14/09/2020)

${ }^{6}$ iSchools Leadership (Board of Directors): https://ischools.org/Meet-OurPeople\#iSchools_Leadership (last accessed 07/10/2020)

${ }^{7}$ Mahony, S, (2017). 'The Digital Classicist: building a Digital Humanities Community', Digital Humanities Quarterly 11:3.

${ }^{8}$ The former being understood here as the weaker bonds of the post industrialisation, urban or capitalistic society and the latter being the closer ties of family and kinship related to Confucian principles; derived from Tönnies (trans. Hollis, 2001)

9 iSchools About: https://ischools.org/About (last accessed 16/09/2020)

10 iSchools regions: https://ischools.org/Regions (last accessed 16/09/2020)

${ }^{11}$ Bogers, Toine; Greifeneder, Elke (2016) The iSchool Community: A Case Study of iConference Reviews, IDEALS www.ideals.illinois.edu/handle/2142/89312 (last accessed 06/10/2020)

12 iSchools Past Proceedings (iConference): https://ischools.org/Past-Proceedings (last accessed 16/09/2020)

13 iConference 2014 Summary: https://ischools.org/iConference-2014-Summary/ (last accessed 09/01/2021)

14 iConference Summary 2015: https://ischools.org/iConference-2015-Summary/ (last accessed 09/01/2021)

${ }^{15}$ Bogers and Greifeneder (2016)

16 iConference 2017 Summary: https://ischools.org/iConference-2017-Summary/ (last accessed 06/10/2020)

17 iConference 2017 Summary: https://ischools.org/iConference-2017-Summary/ (last accessed 06/10/2020)

18 iConference 2017 Summary: https://ischools.org/iConference-2017-Summary/ (last accessed 06/10/2020) 
${ }^{19}$ Bogers and Greifeneder (2016) p. 10

${ }^{20}$ Fiormonte, Domenico. 2012. 'Towards a Cultural Critique of the Digital Humanities', Historical Social Research, Vol. 37 No. 3, 59-76. Reprinted in: Debates in the Digital Humanities 2016, eds Matthew Gold and Lauren Klein (eds) University of Minnesota Press.

${ }^{21}$ Mahony, S. Cultural Diversity and the Digital Humanities. Fudan J. Hum. Soc. Sci. 11, 371-388 (2018). doi.org/10.1007/s40647-018-0216-0 (last accessed 06/10/2020)

${ }^{22}$ Fiormonte, Domenico. 2015. 'Towards monoculture (digital) humanities?' Infolet: Cultura e critica dei media digitali :7. https://infolet.it/2015/07/12/monocultural-humanities. (accessed 07/10/2020) ${ }^{23} 2021$ Chinese Papers: https://ischools.org/Chinese-Papers (accessed 07/10/2020)

24 Crane, Gregory. (2015). 'The Big Humanities, National Identity and the Digital Humanities in Germany'. http://www.dh.uni-leipzig.de/wo/the-big-humanities-national-identity-and-the-digitalhumanities-in-germany. (last accessed 07/10/2020).

${ }^{25}$ Outgoing iSchools Chair 2020: https://ischools.org/resources/Documents/iconf\%202020/iSchoolsOutgoing-Chair-Farewell-Message.pdf (last accessed 07/10/2020)

26 Incoming iSchools Chair 2020:

https://ischools.org/resources/Documents/iconf\%202020/iSchools\%20Chair\%20message.pdf (last accessed 07/10/2020) 